\title{
INFEKSI IRIDOVIRUS PADA INDUK KERAPU LUMPUR (Epinephelus coioides)
}

\author{
Ketut Mahardika"), Isti Koesharyani"), Agus Prijono"), dan Kei Yuasa")
}

\begin{abstract}
ABSTRAK
Pada bulan Januari 2001 terjadi kasus kematian induk ikan kerapu lumpur (Epinephelus coioides) di Balai Besar Riset Perikanan Budidaya Laut, Gondol-Bali. Maksud penelitian ini adalah untuk mengetahui jasad penyebab penyakit dan mengetahui perubahan histopatologi yang terjadi akibat infeksi tersebut. Untuk itu dilakukan beberapa pengamatan meliputi pengamatan parasit dengan pembuatan preparat rentang dan dilihat di bawah mikroskop, isolasi bakteri menggunakan media TSA dan TCBS agar, deteksi virus menggunakan metode PCR dan kerusakan jaringan dengan preparat histopatologi. Ikan yang sakit ditandai dengan tingkah laku ikan yang berdiam di dasar air. Secara anatomi terlihat adanya pembesaran pada organ limpa, tetapi dari ikan-ikan sakit tersebut tidak ditemukan adanya parasit pada insang dan kerokan lendir kulit maupun bakteri yang diisolasi dari organ hati dan limpa. Secara histopatologi, pada ginjal, limpa, hati, dan insang terlihat adanya sel-sel yang membesar yang merupakan ciri khas dari infeksi iridovirus. Sedangkan deteksi virus dengan teknik polymerase chain reaction (PCR) menggunakan spesifik primer, dari organ limpa ternyata positif iridovirus, tetapi deteksi dari organ mata dan gonad negatif dari noda virus sebagai penyebab VNN. Dengan demikian kasus kematian induk ikan kerapu lumpur di Balai Besar Riset Perikanan Budidaya Laut, Gondol-Bali diduga kuat disebabkan oleh infeksi iridovirus.
\end{abstract}

\section{ABSTRACT: Iridovirus infection of orange-spotted grouper (E. coioides) broodstock. By: Ketut Mahardika, Isti Koesharyani, Agus Prijono, and Kei Yuasa}

\begin{abstract}
In January 2001 mass mortalities of culture broodstock orange - spotted grouper (E. coioides) occurred in Research Institute for Mariculture, Gondol-Bali. The aims of this study were to identify the causative agents of the infection and to observe histopathological changes of the organ of infected fish. Parasites were observed by smear preparation and examined under microscope, bacterial identification by biochemical method, and virus by PCR and histopathology. The symptoms of affected fish were lying down and resting on the bottom. Anatomically, enlarged spleen was observed. However, no parasite observed on gill and body surface and not bacteria isolated from liver and spleen of infected fish. Histopathologically, enlarged cell or giant cells were observed in kidney, spleen, liver, and gill. Virus detection from spleen, using polymerase chain reaction (PCR) indicated positive iridovirus. However, noda virus as causative agent of VNN was negative in the eye and gonad. These results indicated that the cause of mortality was iridovirus infection.
\end{abstract}

KEYWORDS: $\quad$ iridovirus, histopathology, PCR, E. coioides

\section{PENDAHULUAN}

Ikan kerapu lumpur, E. coioides merupakan salah satu jenis ikan kerapu yang memiliki nilai ekonomis tinggi. Selama ini kebutuhan akan benih ikan kerapu masih mengandalkan tangkapan dari alam. Oleh karena itu, di Balai Besar Riset Perikanan Budidaya Laut, Gondol-Bali sedang dikembangkan usaha perbenihan kerapu lumpur. Akan tetapi banyak masalah yang harus dihadapi, salah satu di antaranya adalah masalah penyakit.

Kasus kematian massal pada ikan kerapu lumpur pernah terjadi pada jaring tancap (pencage) di Medan, Sumatera Utara (Koesharyani et al., 2001), di panti benih Balai Besar Riset Perikanan Budidaya Laut, Gondol (Mahardika et al., 2001) yang disebabkan oleh infeksi iridovirus. Sebelumnya, kasus kematian ikan kerapu dilaporkan terjadi di Sumatera Utara pada tahun 1993 (Rukyani et al., 1993; Owen, 1993) yang dikenal sebagai penyakit Sleepy Grouper Disease. Infeksi iridovirus ini secara anatomi ditandai dengan pembengkakan pada organ limpa (spleenomegally) dan secara histopatologi ditandai adanya sel-sel yang membesar (heteromorphic ballon cells) (Chua et al., 1994; Jung et al., 1997; Danayadol et al., 1997).

Pada bulan Januari 2001, di Balai Besar Riset Perikanan Budidaya Laut, Gondol terjadi kasus kematian induk kerapu lumpur ( $E$. coioides) di dalam

Peneliti pada Balai Besar Riset Perikanan Budidaya Laut, Gondol

Japan International Cooperation Agency (ATA-379) 
wadah budi daya. Tujuan penelitian ini adalah untuk mengetahui jasad penyebab penyakit dan mengetahui perubahan histopatologi yang terjadi akibat infeksi tersebut. Untuk itu dilakukan beberapa pengamatan yang meliputi pengamatan jasad penyebab penyakit meliputi parasit, bakteri, dan virus memakai metode PCR dengan menggunakan spesifik primer.

\section{BAHAN DAN METODE}

\section{Sampel Ikan}

Tujuh ekor induk ikan kerapu lumpur yang dipelihara dalam satu bak budi daya dengan bobot berkisar antara 5--10 kg yang menunjukkan gejala seperti berdiam di dasar air dan yang mati diambil dan digunakan sebagai sampel ikan.

\section{Pengamatan Parasit dan Bakteri}

Parasit diperiksa dengan cara pembuatan preparat rentang (smear) dari insang dan permukaan kulit kemudian dilihat di bawah mikroskop. Isolat bakteri diambil dari organ hati dan limpa dengan menggunakan jarum ose dan ditanam pada media Tryptone Soya Agar (TSA) dan Thiosulphate Citrate Bile Salt Sucrose Agar (TCBSA) kemudian diinkubasikan pada suhu $27^{\circ} \mathrm{C}$ selama 24 jam.

\section{Deteksi Virus dengan PCR}

Organ mata, gonad, dan limpa diambil dari induk kerapu lumpur, dipotong kira-kira 0,05--0,10 g kemudian dimasukkan ke dalam mikrotube dan disimpan di dalam freezer $\left(-80^{\circ} \mathrm{C}\right)$ sampai digunakan untuk uji PCR. Organ mata dan gonad digunakan untuk deteksi nodavirus sebagai penyebab VNN menggunakan metode yang dikembangkan oleh Yuasa et al. (2001a). Metode ekstraksinya menggunakan ISOGEN (Iwamoto et al., 1999), yang selanjutnya diamplifikasi menggunakan RNA kit Ver. 2.1. Sedangkan primer yang digunakan adalah hasil sekuensing dari striped jack nervous necrosis virus (SJNNV) yaitu primer $R_{3}$ dan $F_{2}$ dengan target bobot molekul T4 426 bp (Nishizawa et al., 1994).

Limpa digunakan untuk deteksi iridovirus diekstraksi dengan menggunakan ISOGEN sebanyak $800 \mathrm{~mL}$ dan disentrifugasi pada $12.000 \mathrm{~g}$ selama 10 menit. DNA diekstrak dengan $200 \mathrm{~mL}$ Chloroform dengan sentrifugasi pada $12.000 \mathrm{~g}$ selama 15 menit, kemudian pellet DNA dicuci dengan alkohol absolut dan alkohol $75 \%$ berturut-turut dan disentrifugasi kembali pada $2.000 \mathrm{~g}$ selama 5 menit. Selanjutnya DNA dikeringkan dalam desikator selama 15-10 menit. Pelet kemudian dilarutkan dalam akuades steril dan siap digunakan untuk amplifikasi (Koesharyani et al.,
2001). PCR amplifikasi menggunakan DNA kit dari promega dan primer yang digunakan adalah hasil sekuensing dari genom DNA red seabream iridovirus (RSIV) yaitu primer $1 \mathrm{~F}$ dan $1 \mathrm{R}$ dengan target bobot molekul 570 bp berdasarkan metode Kurita et al. (1998). Analisis hasil amplifikasi dilakukan dengan elektroforesis $100 \mathrm{~V}$ pada $1,5 \%$ gel agaros menggunakan buffer TAE (2 Na EDTA $2 \mathrm{Na}$, Triss, dan Akuades) selama 20--25 menit. Kemudian dilakukan staining menggunakan ethidium bromide $0,5 \mathrm{mg} /$ $\mathrm{mL}$ dalam bufferTAE. Pembacaan hasil elektroforesis menggunakan ultraviolet transluminator.

\section{Pemeriksaan Histopatologi}

Semua ikan setelah dilakukan pembedahan, dilihat kondisi organ dalamnya. Selanjutnya organ dalam dari masing-masing ikan, (limpa, hati, ginjal, jantung, lambung, usus, insang, mata, dan gonad) dan difiksasi dengan phosphate buffer formalin $10 \%$. Khusus untuk mata dan insang setelah difiksasi dilakukan dekalsifikasi dengan 5\% asam formic dalam phosphate buffer formalin 10\% selama 1--2 hari dan dinetralisasi dengan $5 \% \mathrm{Na}_{2} \mathrm{SO}_{4}$ dalam akuades. Kemudian semua sampel diembadding dalam paraffin wax dan dipotong dengan ketebalan 3--5 mm serta diwarnai dengan haematoxylin-eosin (H\&E).

\section{HASIL DAN BAHASAN}

Secara visual tidak ditemukan kelainan pada bagian luar tubuh ikan seperti adanya luka. Pengamatan secara mikroskopis terhadap preparat segar (insang dan kerokan lendir kulit) tidak ditemukan adanya parasit. Demikian pula bakteri yang diiisolasi dari organ hati dan limpa tidak ada yang tumbuh pada media TSA maupun TCBS agar. Hal ini menunjukkan bahwa kematian induk kerapu lumpur tidak disebabkan oleh infeksi parasit ataupun bakteri.

Induk kerapu lumpur yang sakit menunjukkan gejala seperti nafsu makan menurun, terlihat lemah dan berdiam di dasar air dengan mortalitas mencapai $40 \%$. Secara anatomi, terlihat adanya pembengkakan pada limpa (spleenomegally). Gejala ini sama seperti pada kasus kematian ikan kakap merah, Pagrus major (Inouye et al., 1992; Nakajima \& Sorimachi, 1994; dan Nakajima et al., 1995), ikan kerapu Epinephelus malabaricus (Danayadol et al., 1997; Kasornchandra \& Khongpradit, 1997), brown-spotted grouper ( $E$. tauvina Forskal) di Singapura (Chua et al., 1998), kerapu Epinephelus sp. di Taiwan (Chou et al., 1998), pada kerapu Epinephelus sp. di Indonesia (Owen 1993; Rukyani et al., 1993) yang dikenal dengan nama Sleepy Grouper Disease, pada kerapu lumpur, E. coioides dan dan E. bleekeri (Koesharyani et al., 2001; Mahardika et al., 2001). 
Hasil deteksi virus dengan PCR menggunakan primer spesifik menunjukkan bahwa nodavirus sebagai penyebab VNN tidak terdeteksi dari organ gonad dan mata. VNN merupakan virus yang mematikan terutama menyerang pada stadia larva dan yuwana. Di Indonesia kejadian VNN pernah dilaporkan pada larva ikan kakap, Lates calcarifer (Zafran et al., 1998), pada larva dan yuwana kerapu bebek, Cromileptes altivelis (Zafran et al., 2000). Selain itu VNN juga ditemukan pada ikan kerapu lainnya seperti kerapu batik (E. polyphekadion), kerapu macan ( $E$. fuscoguttatus), dan kerapu lumpur (E. coioides) (Yuasa et al., 2001'). Di Jepang, VNN juga telah terdeteksi dari gonad induk ikan stripped jack, Pseudocaranx dentex dan barfin flounder (Mori et al., 1998; Watanabe et al., 1997 dalam Zafran et al., 1998) yang menunjukkan kemungkinan terjadinya infeksi vertikal dari induk ke telur.

Sedangkan hasil deteksi menggunakan spesifik primer (RSIV) ternyata positif iridovirus. Hal ini terlihat dari gambaran hasil elektroforesis yaitu adanya garis band (570 bp) pada gel agarose. Hasil analisis elektrophoresis untuk kedua virus ini dapat dilihat pada Gambar 1.

Secara histopatologi, dari 5 ekor induk kerapu lumpur pada organ limpa, ginjal depan, dan ginjal belakang terlihat adanya nekrosis sel dan sel-sel yang membesar (Gambar 2, 3, 4). Pada organ hati terlihat adanya akumulasi darah secara tidak normal (Gambar 5) dan pada beberapa ikan ditemukan adanya nekrosis sel-sel hati dengan sel-sel yang membesar di sekitar pembuluh darah. Sel-sel yang membesar juga ditemukan pada lamela insang (Gambar 6), sedangkan pada mata, lambung, usus, jantung, dan gonad tidak ditemukan adanya sel-sel yang membesar. Sel-sel yang membesar atau oleh penelitipeneliti lainnya disebut sebagai ballooned cell, heteromorphic balloon cells, productively infected cells, giant cells, basophilic enlarged cells, merupakan ciri khas dari infeksi iridovirus (Chua et al., 1994; Danayadol et al., 1997; Jung et al., 1997; Chou et al., 1998). Adapun target organ dari iridovirus adalah

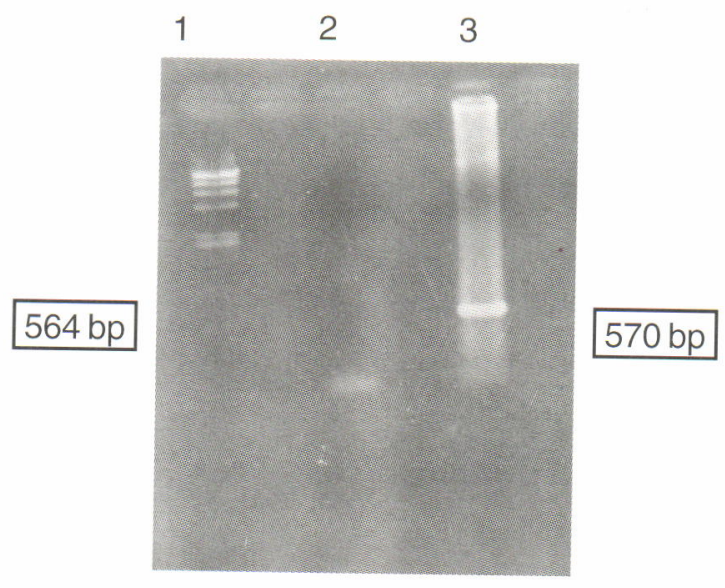

Gambar 1. Deteksi virus dengan PCR pada induk kerapu lumpur (E. coioides) dari hasil elektrophoresis pada gel agarose. 1) marker I HindlII, 2) hasil amplifikasi VNN, 3) hasil amplifikasi iridovirus

Figure 1. Agarose gel elektrophoresis of PCR amplification products from orange-spotted grouper (broodstock). 1) I HindIII marker, 2) VNN amplification product, 3) iridovirus amplification product

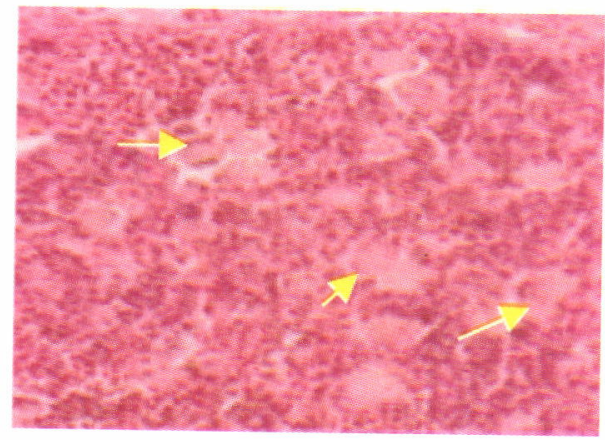

Gambar 2. Sel-sel yang membesar (tanda panah) pada pulpa limpa (pewarnaan H\&E, 40 X)

Figure 2. Enlarged cells (arrow) in spleen pulp (H\&E stain, $40 \mathrm{X}$ ) 


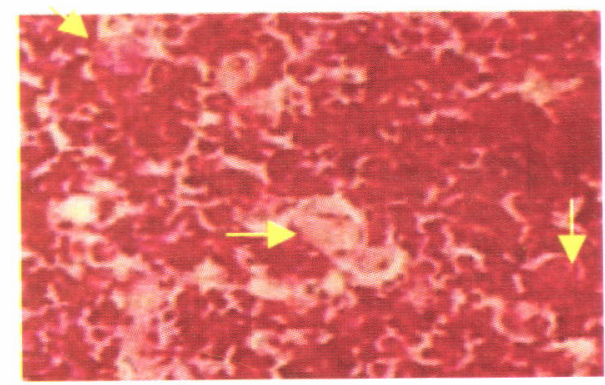

Gambar 3. Sel-sel yang membesar (tanda panah) pada ginjal depan (pewarnaan H\&E, 40 X)

Figure 3. Enlarged cells (arrow) in anterior kidney (H\&E stain, 40 X)

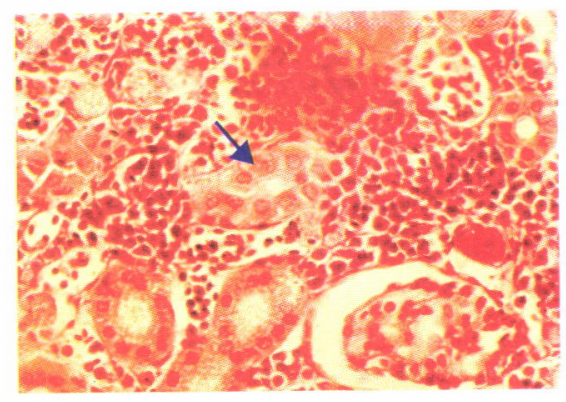

Gambar 4. Sel-sel yang membesar (tanda panah) pada ginjal belakang (pewarnaan H\&E, 40 X)

Figure 4. Enlarged cells (arrow) in posterior kidney (H\&E stain, 40 X)

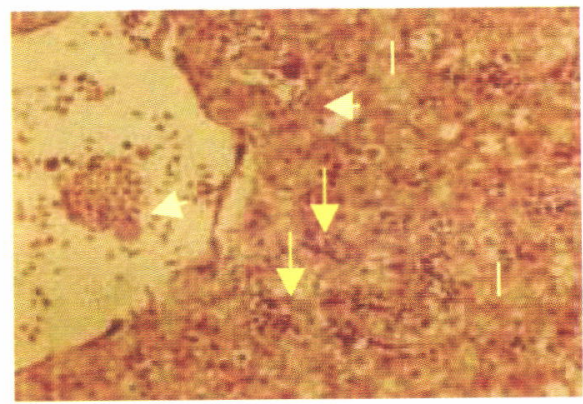

Gambar 5. Akumulasi darah secara tidak normal (tanda panah), sel-sel yang membesar (tanda panah), dan nekrosis sel (garis) pada hati (pewarnaan H\&E, 20 X)

Figure 5. Blood congestion (arrow), enlarged cells (arrow head), and necrosis cells in liver (H\&E stain, 20 X)

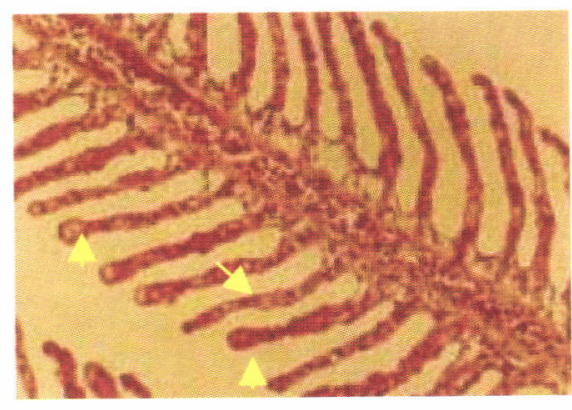

Gambar 6. Sel-sel yang membesar (tanda panah) pada lamela insang (pewarnaan H\&E, 20X)

Figure 6. Enlarged cells (arrow) in gill lamella (H\&E stain, 20X) 
jaringan pembuat darah (haematophoietic tissue) yaitu limpa dan ginjal (Danayadol et al., 1997). Iridovirus merupakan DNA virus yang diklasifikasikan ke dalam famili Iridoviridae, dan dengan elektron mikroskop virus ini berbentuk hexagonal atau icosahedral dengan diameter yang bervariasi yaitu berkisar antara 120-$240 \mathrm{~nm}$ serta berkembang pada sitoplasma sel-sel yang terinfeksi (Inouye et al., 1992; Danayadol et al., 1997; Jung et al., 1997; Chou et al., 1998).

Iridovirus di dalam tubuh ikan diduga menyebar melalui sistem peredaran darah, hal ini ditunjukkan dengan terdeteksinya virus selain pada organ haematopoitik juga dari darah dengan PCR (Kurita et al., 1998). Pengamatan histopatologi menunjukkan adanya sel-sel yang membesar selain dari organ limpa dan ginjal juga ditemukan pada hati, jantung, lambung, usus, pankreas, insang, gelembung renang, tulang, daging, cairan dan choroidal mata, serta selaput otak (Jung et al., 1997; Danayadol et al., 1997; Mahardika et al., 2001).

Di Indonesia, iridovirus selain menginfeksi ikan kerapu pada tahap pembesaran di jaring tancap, jaring apung, dan bak pembesaran atau tambak (Koesharyani et al., 2001; Mahardika et al., 2001; Rukyani et al., 1993; Owen, 1993) juga dapat menginfeksi induk ikan kerapu yang dipelihara dalam bak induk dengan gejala klinis dan perubahan organ dalam baik secara anatomi maupun histopatologi. Adapun faktor pendukung terjadinya kasus ini adalah pergantian air yang kurang memadai (kurang dari $200 \%$ per hari) dan sebelumnya pernah terjadi kasus serupa pada fingerling kerapu lumpur di sekitar lokasi pemeliharaan induk kerapu lumpur seperti dilaporkan oleh Mahardika et al. (2001).

\section{KESIMPULAN}

Iridovirus merupakan jasad patogen penyebab kematian induk kerapu lumpur, E. coioides di dalam bak budi daya (bak induk) di Balai Besar Riset Perikanan Budidaya Laut, Gondol-Bali.

\section{DAFTAR PUSTAKA}

Chou, H.Y., C.C. Hsu, and T. Y. Peng. 1998. Isolation characterization of a pathogenic iridovirus from cultured grouper (Epinephelus sp.) in Taiwan. Fish Pathol., 33: 201--206.

Chua, F.H.C., M.L. Ng, K.L. Ng, I.J. Loo, and J.Y. Wee. 1994. Investigation of outbreaks of a novel disease, Sleepy Grouper Disease, affecting the brown - spotted grouper. Epinephelus tauvina Forskal. J. Fish Dis., 17: $417--427$.

Danayadol, Y., S. Direkbusarakom, S. Boonyaratpalin, T. Miyazaki, and M. Miyata. 1997. Iridovirus infection in brown-spotted grouper (Epinephelus malabaricus) cultured in Thailand. In T. W. Flegel and I. H. MacRae (eds), Diseases in Asian Aquaculture III. Fish Health Section, Asian Fisheries Society, Manila. p. 67--72.

Inouye, K., K. Yamano, Y. Maeno, K. Nakajima, M. Matsuoka, Y. Wada, and M. Sorimachi. 1992. Iridovirus infection of cultured red seabream, Pagrus major. Fish Pathol. (In Japanese with English summary). 27: 19--27.

Iwamoto, T., K. Mori, M. Arimoto, and T. Nakai. 1999. High permissivity of the fish cell line SSN-1 for piscine nodaviruses. Dis. Aquat. Org., 39: 37--47.

Jung, S., T. Miyazaki, M. Miyata, Y. Danayadol, and S. Tanaka. 1997. Pathogenicity of iridovirus from Japan and Thailand for the red sea bream Pagrus major in Japan, and histopathology of experimentally infected fish. Fisheries Science, 63: 735--740.

Kasornchandra, J. and R. Khongpradit. 1997. Isolation and preliminary characterization of a pathogenic iridovirus in nursing grouper, Epinephelus malabaricus. Diseases in Asia Aquaculture III. Fish Health Section, Asian Fisheries Society, Manila, p. 61--66.

Koesharyani, I., K. Mahardika, K. Sugama, and K. Yuasa. 2001. Iridovirus penyebab kematian pada budidaya ikan kerapu lumpur, Epinephelus coioides: Deteksi menggunakan polymerase chain reaction (PCR). Prosiding Seminar Teknologi Budidaya Laut dan Pengembangan Sea Farming di Indonesia. Dep. Kelautan dan Perikanan bekerja sama dengan JICA, p. 228---234.

Kurita, J., K. Nakajima, I. Hirono, and T. Aoki. 1998. Polymerase chain reaction (PCR) amplification of DNA of red sea bream iridovirus (RSIV). Fish Pathol., 33: 17-23 .

Mahardika, K., I. Koesharyani, K. Sugama, A. Prijono, and K. Yuasa. 2001. Studi histopatologi iridovirus pada Epinephelus coioides dan Epinephelus bleekeri. Prosiding Seminar Teknologi Budidaya Laut dan Pengembangan Sea Farming di Indonesia. Dep. Kelautan dan Perikanan bekerja sama dengan JICA, p. 334--341.

Mori, K., K. Mushiake, and M. Arimoto. 1998. Control measures for viral nervous necrosis in striped jack. Fish Pathologi, 33(4): 443--444.

Nakajima, K. and M. Sorimachi. 1994. Biological and physico-chemical properties of the iridovirus isolated from cultured red sea bream, Pagus major. Fish Pathol., 29: 29--33.

Nakajima, K., Y. Maeno, M. Fukudome, Y. Fukuda, S. Tanaka, S. Matsuoka, and M. Sorimachi, .1995. Immunofluorescence test for the rapid diagnosis of red sea bream iridovirus infection using monoclonal antibody. Fish Pathol., 30: 115--119.

Nishizawa, T., K. Mori, T. Nakai, I. Furusawa, and K. Muroga. 1994. Polymerase chain reaction (PCR) amplification of RNA of striped jack nervous necrosis virus (SJNNV).Dis. Aquat. Org, 18: 103--107.

Owen, L. 1993. Report on Sleepy Grouper Disease. Depart. of Biomedical and Tropical Veterinary Science, James Cook Univ. of North Queensland Townsville, Australia, 4.811pp. 
Rukyani, A., P. Taufik, and A. Yuliansyah. 1993. Laporan Survai Kasus Kematian Ikan Kerapu (Grouper) di Daerah Sumatera Utara. Puslitbang Perikanan bekerja sama dengan Dinas Perikanan Tanjung Pinang, $10 \mathrm{pp}$.

Yuasa, K., I. Koesharyani, D. Roza, K. Mahardika, F. Johnny, and Zafran. 2001a. Manual for PCR procedure. Rapid diagnosis on Viral Nervous Necrosis (VNN) in groupers. Gondol Research Institute for Mariculture and Japan International Cooperation Agency. Lolitkanta-JICA Booklet, 13: 12--16.

Yuasa, K., D. Roza, I. Koesharyani, F. Johnny, and K. Mahardika. $2001^{\mathrm{b}}$. The importance of fish pathology mariculture in Indonesia and the role of fish pathologist in sustainable aquaculture. Prosiding Seminar Teknologi Budidaya Laut dan Pengembangan Sea Farming di Indonesia. Dep. Kelautan dan Perikanan bekerja sama dengan JICA, p. 217--226.

Zafran, T. Harada, I. Koesharyani, K. Yuasa, and K. Hatai (1998). Indonesian hatchery reared sea bass larvae (Lates calcarifer), associated with viral nervous necrosis (VNN). IFR Journal, 4(1): 19--22.

Zafran, I. Koesharyani, F. Johnny, K. Yuasa, T. Harada, and K. Hatai. 2000. Viral nervous necrosis in humpback grouper Cromileptes altivelis larvae and juveniles in Indonesia. Fish Pathol., 35: 95--56. 